\title{
Medium- and High-Tech Export and Renewable Energy Consumption: Non-Linear Evidence from the ASEAN Countries
}

\author{
Cong Khai Dinh ${ }^{1}$, Quang Thanh $\operatorname{Ngo}^{1}\left(\mathbb{D}\right.$ and Trung Thanh Nguyen ${ }^{1,2, *(D)}$ \\ 1 School of Government, University of Economics Ho Chi Minh City, Ho Chi Minh City 72407, Vietnam; \\ khai@ueh.edu.vn (C.K.D.); thanhnq@ueh.edu.vn (Q.T.N.) \\ 2 Institute for Environmental Economics \& World Trade, Leibniz University Hannover, \\ 30167 Hannover, Germany \\ * Correspondence: thanh.nguyen@iuw.uni-hannover.de or thanhnt@ueh.edu.vn
}

Citation: Dinh, C.K.; Ngo, Q.T.;

Nguyen, T.T. Medium- and

High-Tech Export and Renewable

Energy Consumption: Non-Linear Evidence from the ASEAN Countries. Energies 2021, 14, 4419. https:// doi.org/10.3390/en14154419

Academic Editor: Surender Reddy Salkuti

Received: 11 June 2021

Accepted: 19 July 2021

Published: 22 July 2021

Publisher's Note: MDPI stays neutral with regard to jurisdictional claims in published maps and institutional affiliations.

Copyright: (c) 2021 by the authors. Licensee MDPI, Basel, Switzerland. This article is an open access article distributed under the terms and conditions of the Creative Commons Attribution (CC BY) license (https:/ / creativecommons.org/licenses/by/ $4.0 /)$.

\begin{abstract}
Sustaining economic growth while reducing dependence on fossil fuels remains a challenge for our world to fight against climate change and therefore finding a way to promote economic growth and increase renewable energy use is needed. This paper uses a 22-year panel dataset (19942015) of 9 countries in the Association of Southeast Asian Nations provided by the World Bank World Development Indicators to examine the impact of medium- and high-tech export on renewable energy use. We employ a fixed-effects regression model with the Driscoll-Kraay nonparametric covariance matrix estimator to account for sectoral and temporal dependence. We also control for inflation, employment, population growth, and gross domestic product per capita in our estimations. Our results demonstrate a U-shaped association between medium- and high-tech export and renewable energy consumption of these economies. The results propose that enhancing medium- and high-tech export could be a feasible solution for promoting renewable energy consumption.
\end{abstract}

Keywords: renewable energy; medium- and high-tech export; economic growth; employment; inflation; ASEAN

\section{Introduction}

Sustaining economic growth while reducing dependence on fossil fuels remains a challenge in our era of climate change. In addition to the need for reducing emissions, continuingly increasing fossil fuel prices, fears of unaffordable and rapidly depleting sources of fossil fuels, and the desire to transitioning into a low carbon economy have combined to heighten the importance of renewable energy use [1]. Several countries have set a target of specific renewable energy share in their total energy consumption. For example, Germany aims to supply electricity solely from renewable energy sources by 2045 . China also pledges to be carbon neutral by 2060 and sets the share of non-fossil fuels in primary energy consumption to around $25 \%$ by 2030 from a previous commitment of $20 \%$. However, increasing renewable energy consumption is not easy for many developing countries, especially for rapidly growing economies as their demand for energy is increasing and their technical and financial capacities for a large-scale supply of renewable energy are limited. In this regard, looking for possible ways to increase renewable energy consumption while maintaining economic growth is required.

Industrialization generally results in a structural transformation from fossil fuelbased and low technology to clean energy-based and medium- and high technology. Medium- and high-tech industries are the value-added manufacturing sectors with higher technological intensity and productivity. They are referred to the level of technology that companies and industries producing goods with innovative qualifications and advanced technologies [2,3]. High technology industries include, for example, aviation and spacecraft industry, pharmaceutical industry, accounting and information processing technologies, 
radio, television and communication equipment industry, and medical and optical devices industry [4]. Thus, the production and export of medium- and high-tech products are an important source of export-oriented growth and development, and of the transition to a low-carbon economy [5-7].

There have been several studies on socio-economic factors affecting renewable energy consumption [8-15]. However, new drivers such as medium- and high-tech export have been given much less attention, especially in the context of developing countries [16]. In addition, existing research mainly explores the competitiveness benefit of the policies on renewable energy use in conventional industrial sectors, such as in iron, steel, paper, and glass industries [17]. Globalization has facilitated trade among countries, and the export of medium- and high-tech products have been promoted in rapidly growing economies. However, so far, the causal effects of trade in general, on renewable energy use in both short- and long- terms are weak and scattered [16,18,19], and the effect of medium- and high-tech export on renewable energy use has not been investigated, especially in the context of rapidly growing economies. This is the main motivation for our study.

Theoretically, high- and medium-tech export affect renewable energy use through three channels. First, higher export of high- and medium-tech goods stimulate domestic production of these exported goods and hence economic growth. Increases in domestic production of these goods and economic growth change the energy demand as energy is a key input for production. This is referred to as the scale effect. Second, trade openness allows countries to exchange energy-saving and cleaner energy technologies, which are exported by developed economies and imported by developing economies [20-23]. Such exchange facilitates technological advancement. This is referred to as the technique effect. Third, economic growth leads to economic structural transformation which means that at the beginning of the transformation when the economy is largely agricultural-based, energy intensity is low. However, at a later stage when industrialization starts, energy intensity increases. At the same time, economic growth makes people better-off and increases their awareness of the environment, thus demand more medium and high-tech goods from environmentally friendly producers. This is referred to as the composite effect. The net effect depends on the stage of economic growth and the changes in consumption patterns of consumers. While developed economies have advantages in improving technologies for promoting renewable energy, developing countries are less able to do so and most of them may rely on technology transfers from developed countries, but for various reasons, technology transfers might be constrained. Therefore, at an earlier stage medium- and high-export from developing countries may still demand more fossil-based resources. Later on, renewable energy use will increase.

We focus our analysis on the nine countries of the Association of Southeast Asian Nations (ASEAN), including Cambodia, Indonesia, Laos, Malaysia, Myanmar, the Philippines, Singapore, Thailand, and Vietnam (hereafter referred to as ASEAN-9 countries). The ASEAN has 10 member countries but we purposely exclude Brunei as its energy consumption solely depends on fossil fuels. Even though these countries differ in several aspects, especially in terms of income per capita (Figure 1), they are commonly known as rapidly growing economies and thus have an increased energy demand. It is projected that the overall primary energy supply will increase from 621 Mtoe in 2015 to 1.544 Mtoe in 2050, an annual increase of 2.6\%; and the gross final energy consumption will increase with an annual rate of $2.4 \%$, from 436 Mtoe in 2015 to 1006 Mtoe in 2050. However, ASEAN remains highly reliant on fossil fuels. Nearly $80 \%$ of the global primary energy supply by 2050 are projected to adhere to fossil fuels. The heavy reliance on fossil fuels along with the decreasing domestic fossil fuel stocks would force the ASEAN's member states to import more fossil fuels. ASEAN is currently the 3rd largest economy in the Indo-Pacific and the 5th largest economy in the world. It has a combined gross domestic product (GDP) of \$US 2.8 trillion, and is also the 3rd fastest-growing major Indo-Pacific economy in the past decade, after China and India (Figure 2). As a critical hub for global trade, over \$3.4 trillion in global trade transits through the ASEAN region each year [24]. Their export of 
medium- and high-tech has also been growing. However, the share of renewable energy in the total energy consumption of these countries is still modest. In this regard, examining the effect of medium- and high-tech export on renewable energy in ASEAN is of particular interest and relevant for policymakers and the public. We use a 22-year panel dataset (1994-2015) of these ASEAN-9 countries provided by the World Bank World Development Indicators to empirically examine the impact of medium- and high-tech export on the share of renewable energy use in total energy consumption of these countries. These countries are diverse in many aspects. For example, Singapore is an advanced economy, Indonesia and Thailand are upper-middle-income countries, Vietnam is a lower-middle-income country, and Cambodia and Laos belong to the group of the least developed countries. Following the arguments in the previous paragraph, we hypothesize that the relationship between medium- and high-tech export and renewable energy consumption in these ASEAN-9 countries is U-shaped.

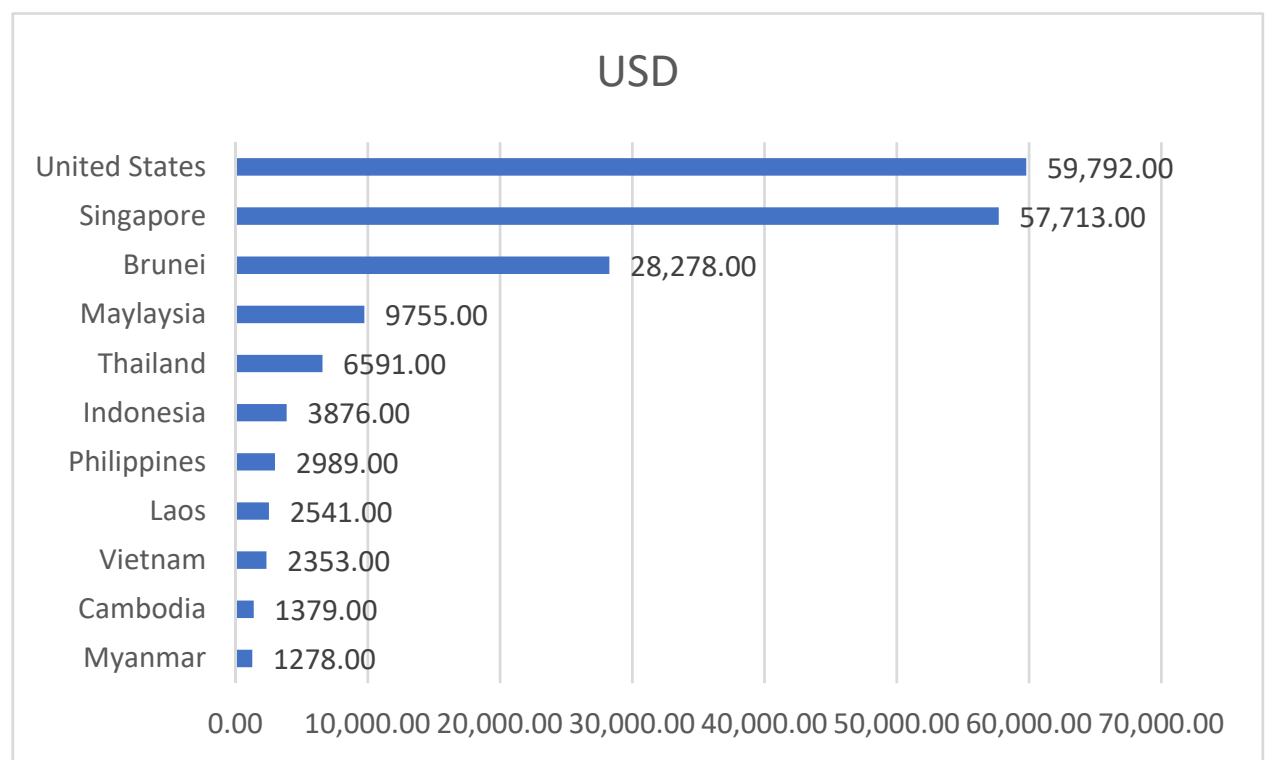

Figure 1. Per capita GDP of the ASEAN economies as compared to the US in 2017. Source: East-West Center, 2019 [24].

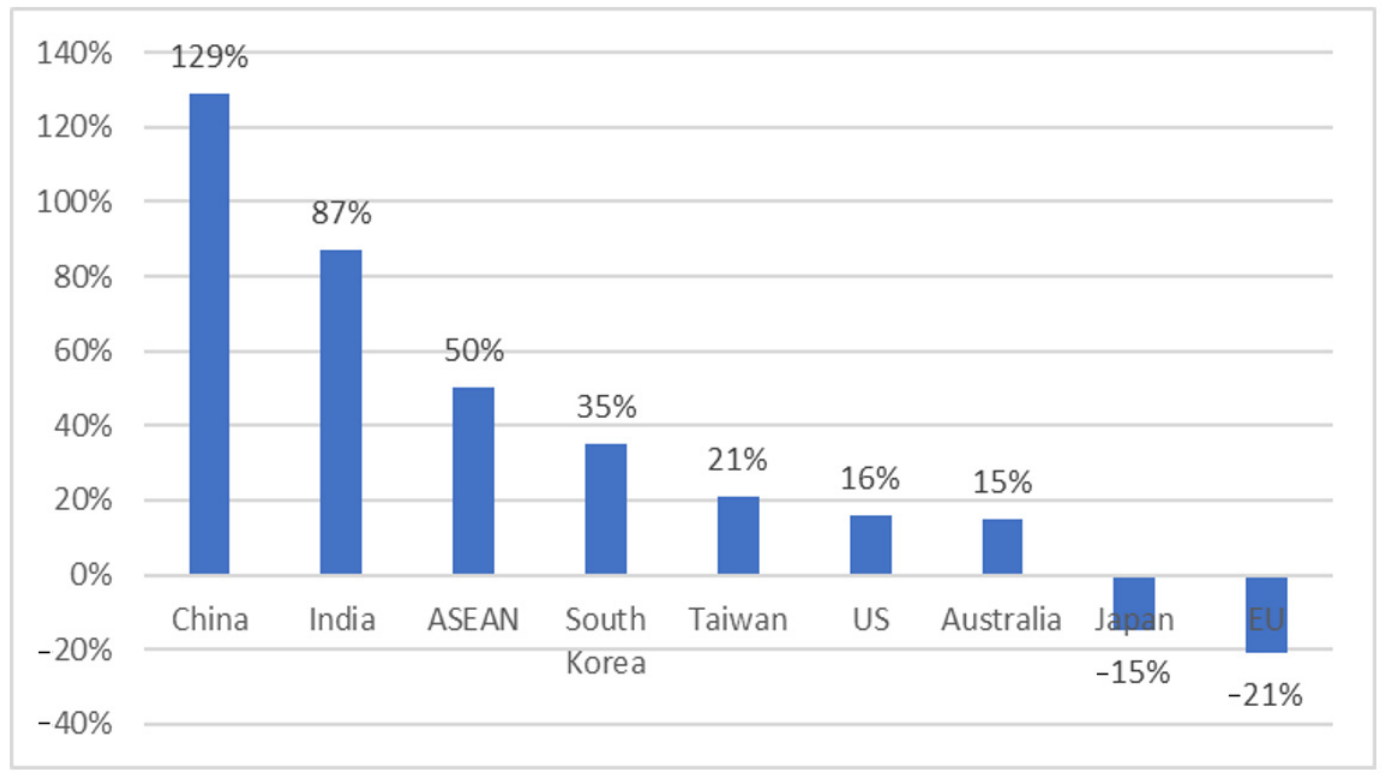

Figure 2. Real GDP growth of ASEAN as compared to some other economies. Source: East-West Center, 2019 [24]. 


\section{Literature Review}

As natural resources in general and fossil fuels in particular, have been depleting, renewable energy use and economic growth are highlighted as major concerns for sustainable development of the global economy [25-29], given the fact that the sustainability of the economic system is dependent on the environment and natural resources [30]. Due to an increasing level of globalization, global energy demand has changed over time and has been driven by trade-related factors. Trade openness, export-oriented policies, and internationalization are considered crucial in the longterm development strategy of many developing countries [31,32]. In this context, recent literature has considered new determinants of energy demand and energy intensity such as export or import product portfolio [33,34], trade openness, and technological advancement [35-38]. In general, there is a controversy on the effect of trade on energy intensity. On the one hand, many studies find that trade openness positively affects energy intensity [39-45]. On the other hand, the effect can be adverse [46], or ambiguous [47] depending on competitiveness, factor price, and technology and infrastructure factors $([35,48])$. Regarding the spectrum of trade and innovation, Samargandi [35] reveals that trade openness and innovation are significant factors for reducing energy intensity. Beser and Soyyigit [2] indicate that high-tech export has a strong impact on $\mathrm{CO}_{2}$ emission in developed economies.

The importance of technology in determining energy use and energy efficiency in developing countries is increasing due to a growing level of internationalization and integration $[22,49,50]$. Technology innovation induced by investment in research and development and by foreign direct investment is supposed to increase energy use efficiency [40]. Domestic innovation is also an important contributor to technical development $[49,51]$. To mitigate the negative effects of climate change, technological progress is crucial [52], and increased R\&D is associated with more technical innovation and renewable energy adoption [53] in both developed and developing countries, where renewable energy sources such as biomass, solar, wind and hydropower are adopted $[54,55]$. Recent studies on the relationship between technological advancement and carbon emission demonstrate positive effects of technology innovations on carbon emission reduction [56-58]). Liu, Xia, Tao, and Chen [56], for instance, analyze carbon emission in China and find that increasing technological expenditure could in turn increases carbon emission efficiency. Wang, Zhao, Wang, Guo, Kan, and Yuan [57] discover that investments in technology decrease carbon emissions. Zeng, Lu, Liu, Zhou, and $\mathrm{Hu}$ [58] find that foreign trade, foreign capital, and technological progress have positive effects on carbon emission reduction.

Several studies examine the drivers of renewable energy use. Most of these indicate the causal interactions between economic growth and renewable energy use [59-62], between renewable energy use and sustainable development [63-65], between energy use and trade openness, and between technological progress and renewable energy use. For example, Apergis and Payne [61] investigate the relationship between economic growth and renewable energy use of 20 OECD countries during 1985-2005 and find a bidirectional link between economic outcome and energy use. Fang and Chang [62] analyze the causality between energy use and economic performance in 16 countries of the Asia Pacific and finds a long-run cointegrating relationship. Kahia et al. [66] examine the relationship between energy use and economic growth, using a sample of 7 MENA Net Oil Importing Countries (NOICs) during 1980-2012; and their empirical results confirm the bidirectional causality between renewable energy use (and non-renewable energy use) and economic growth. Le and Sarkodie [67] investigate the nexus between renewable and conventional energy and economic growth, using panel data of 45 Emerging Market and Developing Economies (EMDEs) from 1990 to 2014. They find that renewable energy and GDP growth impact each other. Marques and Fuinhas [68], using a sample of 24 European countries during 1990-2006, find that the current level of renewable energy use is positively dependent on the previous level of renewable energy use. However, income and prices of fossil- 
based fuels are not significant for the development of renewable energy during the studied period. Ahmed et al. [69] investigate the interactions between renewable and non-renewable energies, $\mathrm{CO}_{2}$ intensity, and economic growth in Myanmar during 19902016; and their results reveal that renewable energy use significantly promotes economic growth.

Few studies have also examined the relationship between trade openness, technological innovation, and (renewable) energy use (Alam and Murad [16], Sohag, Begum, Abdullah, and Jaafar [22], Sbia et al. [70,71], Khan et al. [72], Cole [47], Shahbaz, Nasreen, Ling, and Sbia [21]). Alam and Murad [16] reveal that economic growth, trade openness, and technological progress significantly influence renewable energy use in 25 OECD countries. Sohag, Begum, Abdullah, and Jaafar [22] employ a dataset during 1985-2012 in Malaysia and find that while economic growth and trade openness are the main determinants of energy use, technological innovation reduces energy use in manufacturing sectors. Sbia, Shahbaz, and Hamdi [70] examine the impacts of foreign direct investment, trade openness, clean energy price, carbon emissions, and economic growth on the demand for energy in the United Arab Emirates. Their findings indicate that trade openness and foreign direct investment reduce energy use because energy-efficient technologies have been employed. By comparing upper-middle-income countries in Asia, Europe, Africa, and America, Khan, Yaseen, and Ali [72] indicate that trade can induce technology transfer for renewable energy. Shahbaz, Nasreen, Ling, and Sbia [21] use the data from 91 high, middle, and low-income economies and conclude that domestic energy use is affected by trade openness through several channels such as technological transfers, economies of scale, and input factors. In high-income economies, an inverted U-shaped relationship between trade openness and energy consumption is found. According to Shahbaz, Nasreen, Ling, and Sbia [21], the U-shaped relationship between trade openness and energy consumption exists when low and middle-income countries import or use energy-efficient technologies from developed countries to lower energy consumption, on the one hand; and on the other hand, when developed countries allow to release those technologies and share profits for low and middle-income countries that have limited access to technology and capital.

A most recent study that is close to our work in terms of geographical coverage (for ASEAN with a 22-year span of time) is Azam, Khan, Zaman, and Ahmad [25], who find that trade openness has a positive relationship with energy consumption in Thailand, Malaysia, and Indonesia. Apart from trade openness, they discover that population growth increases the energy consumption in Malaysia, while it decreases energy consumption in Indonesia. Real GDP is found to have a positive relationship with energy consumption in Thailand, Malaysia, and Indonesia.

The causal effects between international trade (exports or imports) and renewable energy use in both short- and long- terms that have been found so far are weak [16]. The results from Sadorsky [20] for a sample of Middle Eastern countries show that international trade increases domestic use of energy. In addition, Shahbaz, Nasreen, Ling, and Sbia [21] conclude that a U-shaped relationship exists for high-income countries, whereas an inverted U-shaped relationship is found for middle- and low-income countries for the relationship between international trade and energy use.

In sum, none of the previous studies examine the impact of medium-and high-tech export on renewable energy use. Our study is thus aimed to contribute to filling this gap. The contribution of our study to the literature are two-fold. First, our study is the first effort to examine the effects of medium- and high-tech export on renewable energy share in total energy consumption for this group of rapidly expanding economies. To our best knowledge, only Shahbaz, Nasreen, Ling, and Sbia [21] discover non-linear relationships between trade openness and energy consumption for two country groups, high-income countries and middle- and low-income countries. Second, from a methodological perspective, we use panel data and employ a fixed-effects regression model with the Driscoll-Kraay nonparametric covariance matrix estimator to account for unobservable time-invariant 
factors and sectoral and temporal dependence. These concerns have not been successfully addressed in many previous studies (Azam et al. [25]).

\section{Data and Methods}

\subsection{Data Source}

We extract the data needed for our study from the World Bank World Development Indicators (WDI). This database has been established for years in many countries. For the ASEAN countries, the data are available from 1994 to 2015. This allows us to establish a balanced panel dataset for these nine ASEAN countries. As explained above, we exclude Brunei from the sample since it is an outlier in terms of renewable energy use. Our variables of interest are medium- and high-tech export, and renewable energy use of these countries over time as we would like to investigate the association between these two important variables. From the literature review presented in the previous section, it is clear that a direct relationship between them can be established.

We use the share of renewable energy in the total energy consumption of each country in each year (\% of total final energy consumption) to represent renewable energy use. It is the explained variable. For explanatory variables, the share of medium- and high-tech export in total manufactured export (\% of manufactured export) is our key variable of interest. In addition, we control for inflation, employment, population growth, and GDP per capita. Inflation is measured as the change in the consumer price index $(\%$, year 2010 is the base year, $2010=100$ ), employment is measured as the share of employment in the industrial sectors in total employment of an economy in each year (\% of total employment) while population growth is also reported annually for each country. The GDP per capita is measured in purchasing power parity (PPP, constant 2017). These variables are coded as follows: REU for renewable energy share (\%), MHTE for medium- and high-tech export share in total manufactured export (\%), INF for inflation (\%), POPG for population growth $(\%), E M P$ for the employment share in industry (\%), and GDPPC for GDP per capita (PPP, constant 2017). All these variables are annual for these ASEAN-9 countries from 1994 to 2015. A more detailed definition of these variables is in Appendix A. The description of the data for each country is presented in Table 1 whereas Table 2 summarizes the data for the whole block. These tables show the REU mean value is 42.673 (\%), the mean value of MHTE is $37.168(\%)$, while the mean value of INF is 77.034 (\%). On average, POPG is $1.575 \%$, EMP is $17.915(\%)$, and GDPPC is 13,417 (USD PPP 2007). The correlation coefficients between these variables are in Appendix B which show that NHTE, INF, POPG, EMP, and GDPPC all have a negative association with $R E U$ at a $1 \%$ level of significance.

Table 1. Descriptive statistics of variables of each ASEAN country (1994-2015).

\begin{tabular}{cccccccccccccc}
\hline Country & \multicolumn{2}{c}{ REU $(\%)$} & \multicolumn{3}{c}{ MHTE $(\%)$} & \multicolumn{2}{c}{ INF $(\%)$} & \multicolumn{2}{c}{ POPG $(\%)$} & \multicolumn{2}{c}{ EMP (\%) } & \multicolumn{2}{c}{ GDPPC (USD PPP, 2007) } \\
\hline & Mean & SD & Mean & SD & Mean & SD & Mean & SD & Mean & SD & Mean & SD \\
\hline Cambodia & 75.59 & 6.58 & 3.34 & 2.93 & 76.00 & 25.42 & 2.01 & 0.63 & 12.99 & 5.50 & 2118 & 789 \\
Indonesia & 42.65 & 4.63 & 29.22 & 3.70 & 69.59 & 36.22 & 1.38 & 0.08 & 19.03 & 1.29 & 7150 & 1501 \\
Laos & 75.94 & 9.94 & 5.45 & 4.34 & 68.51 & 40.83 & 1.72 & 0.27 & 6.43 & 2.43 & 3858 & 1329 \\
Malaysia & 5.79 & 1.63 & 67.45 & 6.13 & 88.99 & 13.80 & 2.00 & 0.42 & 30.19 & 2.17 & 18,262 & 3316 \\
Myanmar & 80.64 & 6.29 & 1.66 & 2.78 & 55.45 & 43.77 & 0.94 & 0.23 & 14.36 & 2.28 & 2080 & 1175 \\
Philippines & 32.64 & 3.78 & 73.81 & 10.44 & 79.34 & 23.13 & 1.94 & 0.27 & 15.51 & 0.39 & 5230 & 966 \\
Singapore & 0.51 & 0.08 & 68.87 & 16.55 & 92.89 & 11.308 & 2.33 & 1.44 & 25.03 & 4.45 & 65,782 & 14,060 \\
Thailand & 21.85 & 1.27 & 58.68 & 3.99 & 87.08 & 15.89 & 0.74 & 0.28 & 20.50 & 1.65 & 12,286 & 2386 \\
Vietnam & 48.45 & 11.12 & 26.04 & 10.84 & 75.46 & 37.01 & 1.13 & 0.26 & 17.20 & 4.26 & 3986 & 1337 \\
\hline
\end{tabular}

Source: Authors' estimation based on WDI database; SD: Standard deviations. 
Table 2. Descriptive statistics of variables of nine ASEAN countries (1994-2015).

\begin{tabular}{ccccc}
\hline Variable & Mean & \multicolumn{3}{c}{ SD } \\
\cline { 3 - 5 } & & overall & between & within \\
\hline REU $(\%)$ & 42.67 & 29.26 & 30.29 & 8.07 \\
MHTE $(\%)$ & 37.17 & 29.70 & 30.26 & 29.23 \\
INF $(\%)$ & 77.03 & 31.26 & 11.72 & 0.57 \\
POPG (\%) & 1.58 & 0.77 & 0.55 & 3.07 \\
EMP (\%) & 17.92 & 7.24 & 6.93 & 4877 \\
GDPPC (USD PPP, 2007) & 13,419 & 1983 & 20,340 & \\
\hline
\end{tabular}

Source: Authors' estimation based on WDI database; SD: Standard deviations; No. observations: 198; No. of countries: 9; No. of years: 22.

\subsection{Methods}

We employ an econometric analysis to examine the effect of the explanatory variable (medium- and high-tech export) on the explained variable (renewable energy share). Following previous studies, we control for GDP per capita, inflation, employment, and population growth as these factors have been found to influence energy use. They are the factors affecting energy demand. GPD per capita, inflation, and employment are key drivers of changes in purchasing power parity; and for population, Samargandi [35] argues that population growth positively influences energy usage and energy intensity, which might be harmful to the environment. The employment share of the industry might have either a positive or a negative on renewable energy use [73-75]. For the effects of these factors on energy use, see [7,16,20-22,35] for GDP, [73,74] for inflation, [75] for employment, and $[35,76]$ for population growth. A factor affecting renewable energy use is its price. The declining price of renewable energy driven by technological progress could be important in increasing the renewable energy share in total energy consumption. Unfortunately, we cannot collect sufficient data. Oil price could be another significant factor. However, as some studies find the least influence of oil price on renewable energy production $[7,8,11,20]$, or insignificant [77], especially in the case of oil-exporting countries like these ASEAN-9 countries, and/or in the case that these countries have subsidized oil prices to avoid any adverse effect of oil price fluctuations on the economy [11]. In addition, incorporating oil prices in our analysis could lead to an endogenous issue that must be addressed. Therefore, we excluded prices factors in our analysis.

Econometrically, the causal relationship could be examined using either a pooled ordinary least square (OLS) technique or the panel data method, including either a fixedeffects model (FEM) or a random-effects model (REM) [78]. To choose either the OLS technique or the panel data method, we conducted an F-test for the joint significance of differing group means. Results of the F-test presented in Appendix C $(F(8,184)=76.97$ with $p$-value 0.0000) indicate the null hypothesis that the pooled OLS model is appropriate is rejected. Thus, panel data analysis was chosen. We advanced further to choose either FEM or REM by performing a Hausman test. Results of this test in Appendix $C$ indicate the FEM is a more suitable specification. From a theoretical point of view, FEM has the advantage of controlling for time-invariant unobservable factors. An alternative test to choose either FEM or REM was the overidentifying restriction test $[79,80]$ which also indicates that the FEM model is a more suitable specification (results of this test in the last two rows in Appendix C). In addition, FEM is also recommended to estimate the parameters for a small cross-sectional sample [81] which is our case as we have only 9 countries. Our specification is also in line with previous studies on factors affecting renewable energy use such as Bamati and Raoofi [7] for 25 developed and developing countries, Alam and Murad [16] for 25 OECD countries, Azam, Khan, Zaman, and Ahmad [25] for three ASEAN countries (namely Indonesia, Malaysia, and Thailand); Kahia, Aïssa, and Lanouar [66] for 7 MENA Net Oil Importing Countries; Marques and Fuinhas [68] for 24 European countries; Sadorsky [20] for eight Middle Eastern countries; Bashir, Sheng, Doğan, Sarwar, 
and Shahzad [31] for 29 OECD countries; Beser and Soyyigit [2] for G20 countries (except Russia), Chen, Du, Huang, and Huang [5] for 34 industrial sectors in China, and Waheed et al. [82] for 6 Gulf Cooperation and Council countries.

Therefore, our econometric regression model is specified as follows (Equation (1)):

$$
R E U_{i t}=\alpha_{0}+\beta_{1} M H T E_{i t}+\beta_{2} I N F_{i t}+\beta_{3} P O P G_{i t}+\beta_{4} E M P_{i t}+\beta_{5} P G D P C_{i t}+v_{i}+e_{i t}
$$

where REU is the share of renewable energy in total energy consumption; MHTE is the share of medium- and high-tech export in total export; INF is the inflation rate; POPG is the population growth rate; EMP is the employment share of industry (\%), and GDPPC is GDP per capita (PPP, constant 2017) as defined in Section 3.1 (see Tables 1 and 2). Subscripts $i$ and $t$ denote country and time, respectively; $\alpha$ is the fixed country effect while $v_{i}$ is the country-specific effect, and $e_{i t}$ is the error term.

Several tests were undertaken to ensure the validity of our regression model. First, to control for possible multicollinearity between explanatory variables, the variance inflation factor (VIF) values were checked $[83,84]$ and the results documented in Appendix D do not signal that problem. Second, as our sample is small in terms of both the number of countries ( 9 countries) and the number of time periods (22 years), we undertook the following tests: (i) Modified Wald test for group-wise heteroskedasticity, (ii) the BreuschPagan LM test for cross-sectional dependence [85,86]; (iii) the slope homogeneity test introduced by Swamy [87], and (iv) the stationarity test for each variable.

Cross-sectional heterogeneity should be controlled for when conducting a panel data empirical analysis [88]. Swamy [87] proposes the homoskedasticity assumption test for the slope homogeneity assumption. Results of this test presented in Appendix E show that we can reject the null hypothesis of the slope homogeneity for our sample. In addition, results of the Breusch-Pagan LM test of independence (also in Appendix E) indicate that the null hypothesis of no cross-sectional independence is rejected at the $1 \%$ level of significance, indicating strong cross-sectional dependence.

Once there is cross-sectional dependence across countries in the panel, it is needed to perform the cross-sectionally augmented Dickey-Fuller (CADF) procedure from Pesaran [89]. Results presented in Appendix F show that we were not able to reject the null unit root hypothesis for the GDPPC series; but when taking the first difference, the null hypothesis of the unit root is rejected for variables POPG and INF. However, this is not sufficient for us to conclude that there is a long-run equilibrium relationship among the concerned variables, namely REU, MHTE, INF, EMP, POPG, and GDPPC.

Given the presence of cross-sectional dependence and/or heteroscedasticity, we adopted our FEM with Driscoll-Kraay standard errors. According to Hoechle [90], the Driscoll-Kraay standard errors are heteroskedasticity-, and autocorrelation-, consistent and robust to general forms of cross-sectional and temporal dependence.

\section{Findings and Discussion}

\subsection{Findings}

Table 3 presents the results of our estimation, including both a normal fixed effects specification and the fixed effects specification with the Driscoll-Kraay standard errors. The R squared value of 0.718 from these two specifications indicates that shows our model can predict about $72 \%$ of the variation in the share of renewable energy in total energy consumption.

Regarding the effect of medium- and high-tech export, Table 3 shows that the mediumand high-tech export has a significant U-shaped relationship with the share of renewable energy use of these ASEAN-9 countries. This U-shaped relationship implies that at the beginning stage of economic development, a higher level of medium- and high-tech export would lead to a lower share of non-renewable energy in total energy consumption. However, once the economy has reached a certain level of medium- and high-tech export, then the higher the level of medium- and high-tech export, the higher the share of renewable energy in the total energy consumption of that economy. In our case, the threshold value for 
the turning point of the U-shaped relationship is $64.47 \%$. Within these ASEAN-9 countries, Malaysia and Singapore have passed this turning point since 1994, and the Philippines since 1995.

With regards to the controlled variables, inflation, employment in the industry sector, and GDP per capita are significantly and negatively associated with the share of renewable energy in total energy consumption, meanwhile, population growth is significantly and positively associated with the share of renewable energy.

Table 3. Impact of medium- and high-tech export on renewable energy share.

\begin{tabular}{ccc}
\hline Variable & Normal Fixed Effects Model & $\begin{array}{c}\text { Fixed Effects Model with xxx } \\
\text { Driscoll-Kraay Standard Errors }\end{array}$ \\
\hline MHTE & $-0.420^{* * *}(0.105)$ & $-0.420^{* *}(0.163)$ \\
MTE, squared & $0.0036^{* * *}(0.0011)$ & $0.0036^{* *}(0.0015)$ \\
INF & $-0.0895^{* * *}(0.0133)$ & $-0.0895^{* * *}(0.0130)$ \\
POPG & $0.989^{*}(0.518)$ & $0.989^{*}(0.476)$ \\
GDPPC & $-0.719^{* * *}(0.121)$ & $-0.719^{* * *}(0.199)$ \\
Constant & $-7.29 \times 10^{-5}\left(7.32 \times 10^{-5}\right)$ & $-7.29 \times 10^{-5}(0.0001)$ \\
No. of observations & $69.28^{* * *}(2.460)$ & $69.28^{* * *}(3.043)$ \\
No. of time periods & 198 & 198 \\
No. of countries & 22 & 22 \\
MHT and MHTE squared are & 9 & 9 \\
jointly equal to zero & $\mathrm{F}(2,183)=8.46$ & $\mathrm{~F}(2,8)=3.32$ \\
Overall R squared & Prob $>\mathrm{F}=0.0003$ & Prob $>\mathrm{F}=0.0890$ \\
\hline
\end{tabular}

Source: Authors' estimation, standard errors in parentheses, ${ }^{* * *}, * *$, and * denote statistical significance at the $1 \%, 5 \%$, and $10 \%$ levels, respectively.

\subsection{Discussion}

With respect to the influences of medium- and high-tech export on renewable energy use, our results indicate that medium- and high-tech export has a U-shaped association with renewable energy use in the ASEAN-9 countries. A couple of previous studies have not found any short- and long-term effects of trade on renewable energy use [8,91]. Our finding is a contribution to a new strand of literature on the non-linear effects of trade on resource use. This strand includes, for example, Shahbaz, Nasreen, Ling, and Sbia [21] who find the pattern of a U-shaped relationship exists in high-income countries, and an inverted U-shaped relationship in the middle- and low-income countries for the relationship between international trade and energy use.

Most previous studies so far have found only a positive effect of high-tech export. It is generally argued that under high-tech export orientation, there is peer-to-peer lending which enables them to adopt such technology that uses lower energy; in addition, different technologies and resources can be shared. Thus, energy consumption is also shared and reduced and it helps save energy costs, including renewable energy [2,7]. Bamati and Raoofi [7] provide an analysis of the influence of high-tech export on renewable energy production by levels of development and find that high-tech export increases renewable energy production for 10 developed countries, but for 15 developing countries the effect is insignificant. A stronger effect of high-tech export on developed countries rather than developing countries is also confirmed by Beser and Soyyigit [2] with a sample of the G20 countries (except Russia).

Our result can be explained by the fact that, in terms of medium- and high-tech export, most of the ASEAN-9 countries do not seem to have high shares of high-tech export or at least technologies that could affect promoting renewable energy use. This means, at a lower level of development, the effect is negative but later on, it turns out to be positive.

Renewable energy use is upon the spending and expectations toward the behaviors of consumers that are affected by different aspects of inflation [92-94]. While depicting the 
concern of medium- and high-tech export toward renewable energy use, the controlled factors have a specific influence on renewable energy use in the ASEAN-9 countries. This is widely stated by the variables like GDP per capita and employment. Inflation is also counted as a major factor that influences renewable energy use. Inflation has a dominant impact on economic performance due to the implications of targeting the environment by high inflation [73]. Our results indicate that inflation has a negative relationship with renewable energy use. These results are supported by Kosai, Yuasa, and Yamasue [74]. Although prices of various products are associated with inflation and wide interpretation enhances the role of renewable energy use in the ASEAN-9 countries, a hike in prices of various goods and services induces a significant impact on renewable energy use. Therefore, inflation with the relevance of medium- and high-tech export inserts a negative role toward the renewable energy use of many ASEAN-9 countries [95]. It could be due to the devaluation of the currency that renders renewable energy use with a hike in prices. Inflation could help in uplifting the economies of various countries but could lead to some adverse effects too.

Our regression model shows that population growth has a positive effect on renewable energy use. In fact, the introduction of technology and innovation in renewable energy use has increased the demand of the population for renewable energy. While enumerating the ecological problems with energy-related factors, population growth is the main driver of environmental degradation [96]. Therefore, population growth might result in a negative contribution toward renewable energy use. Our results contribute, to some extent, to this disputable discussion. Recall that Azam, Khan, Zaman, and Ahmad [25] when examining the impact of various factors on energy consumption in three ASEAN countries (Indonesia, Malaysia, and Thailand) in the period 1980-2012, find that population growth increases the energy consumption in Malaysia, while it decreases energy consumption in Indonesia.

The advantage of renewable energy use is indisputable. It is upon the governments of these ASEAN-9 countries to induce needed measures to promote energy use. Potential impacts of employment on renewable energy use in various industries are evident with local renewable resources [97]. Many ASEAN-9 countries have contributed to a significant rise in the employment rate due to its influence on renewable energy use. For the regional development policy of renewable energy use, the employment regimes and challenges insert an important role [98]. The improper sharing of the economy has been eliminated by the positive enclosure of employment elements that widely induce technological innovation in ASEAN-9 countries.

The empirical results also show that GDP per capita has a negative but insignificant effect on renewable energy use. The result is in line with Marques and Fuinhas [68] who investigate drivers promoting renewable energy in 24 European countries and find that the per capita income (in natural logarithm) is not statistically significant in explaining the use of renewables. A negative effect is found by Waheed, Sarwar, and Mighri [82], and Samargandi [35]. Samargandi [35], for example, examines the impacts of trade openness, technological innovation, and energy price on energy intensity in OPEC countries, in which GDPPC is used as a controlling variable.

\section{Conclusions}

Our study investigates the influences of medium- and high-tech export on the renewable energy use of nine ASEAN countries in the period 1994-2015. We control for inflation, population growth, employment, and GDP per capita. Our findings suggest that mediumand high-tech export reduces the share of renewable energy in total energy consumption during an earlier stage of economic development but then increases the share of renewable energy consumption during the later stage of economic development. This seems to be a characterized feature observed in these ASEAN-9 countries, contributing to the complexity of trade-renewable energy nexus in the literature. Our study also elaborates that under high inflation, individuals and firms cannot afford costly high technology, effective techniques, and skilled human resources, which consume a smaller amount of renewable energy in 
production. Growth in the population provides human resources and at the same time promotes renewable energy use. High employment opportunities indicate high economic growth, which can help to save energy.

Our study has some limitations despite its theoretical and empirical importance. First, due to the availability of the data provided by the World Bank in the World Development indicator, we are not able to control for other factors such as oil prices and/or price of renewable energy that might have significant effects on renewable energy use. Therefore, our results should be interpreted with care. Second, our study is at the macro level and thus not on the behavior of individual energy users (i.e., firms and businesses). The changes in the behavior of energy users should be examined as well to provide a better understanding of energy transition. Third, our sample is small with only nine ASEAN countries in a short-term period. Expanding the study to cover more countries in a longer time period would provide a more comprehensive picture of the effect of medium- and high-tech export on renewable energy use. Last, we are unable to undertake a measurement uncertainty analysis [99]. These issues should be themes for future studies.

Author Contributions: Conceptualization, T.T.N., and Q.T.N.; methodology, T.T.N.; data curation, Q.T.N.; writing—original draft preparation, T.T.N., Q.T.N., C.K.D.; writing—review and editing, T.T.N., Q.T.N., C.K.D.; project administration, T.T.N.; funding acquisition, Q.T.N. All authors have read and agreed to the published version of the manuscript.

Funding: This research is funded by the University of Economics Ho Chi Minh City, Vietnam.

Data Availability Statement: The data presented in this study are available on request from the corresponding author.

Conflicts of Interest: The authors declare no conflict of interest. The funders had no role in the design of the study; in the collection, analyses, or interpretation of data; in the writing of the manuscript, or in the decision to publish the results.

\section{Appendix A. Definition of Variables Used in the Analysis}

\begin{tabular}{cl}
\hline Variable & \multicolumn{1}{c}{ Definition \& Measurement } \\
\hline REU & $\begin{array}{l}\text { Share (\%) of renewable energy consumption in total final energy consumption in } \\
\text { a year of a country }\end{array}$ \\
& Change (\%) in consumer price index with year 2010 as the base year (100\%). It \\
& reflects changes in the cost to the average consumer of acquiring a basket of \\
& goods and services that may be fixed or changed at specified intervals. It is \\
annual for each country.
\end{tabular}

Source: WDI. 
Appendix B. Correlation Matrix of the Variables Used in the Analysis

\begin{tabular}{|c|c|c|c|c|c|c|}
\hline Variable & $R E U$ & MHTE & INF & POPG & EMP & GDPPC \\
\hline REU & 1.0000 & & & & & \\
\hline MHTE & $-0.9015^{* * *}$ & 1.0000 & & & & \\
\hline$I N F$ & $-0.4541^{* * *}$ & $0.3562 * * *$ & 1.0000 & & & \\
\hline POPG & $-0.1662^{* * *}$ & $0.2578^{* * *}$ & $-0.1246^{*}$ & 1.0000 & & \\
\hline$E M P$ & $-0.8293^{* * *}$ & $0.6782^{* * *}$ & $0.4239 * * *$ & 0.07722 & 1.0000 & \\
\hline GDPPC & $-0.6737^{* * *}$ & $0.5109^{* * *}$ & $0.3077^{* * *}$ & $0.2964^{* * *}$ & $0.4741^{* * *}$ & 1.0000 \\
\hline
\end{tabular}

${ }_{* * *},{ }^{* *}$, and ${ }^{*}$ : Significant at the $1 \%, 5 \%$ and $10 \%$ level, respectively. Source: Authors' estimation.

Appendix C. F test, Hausman Test, and Test of Overidentifying Restrictions

\begin{tabular}{cc}
\hline F Test & Coef. \\
\hline F test that all $\mathrm{u}$ i $\mathrm{i}=0: \mathrm{F}(8,184)$ & 76.97 \\
$p$-value & 0.0000 \\
\hline Hausman Test & Coef. \\
\hline Chi-square test value & 40.83 \\
$p$-value & 0.0000 \\
\hline Test of overidentifying restrictions: fixed vs. \\
$\quad$ random effects \\
\hline Sargan-Hansen statistic Chi-sq(5) \\
$\quad$-value \\
\hline Source: Authors' estimation. \\
\hline
\end{tabular}

Appendix D. Variance Inflation Factor (VIF) Value

\begin{tabular}{ccc}
\hline Variable & VIF & 1/VIF \\
\hline MHTE & 2.15 & 0.464597 \\
EMP & 2.08 & 0.479953 \\
GDPPC & 1.53 & 0.651664 \\
INF & 1.33 & 0.753238 \\
POPG & 1.23 & 0.813535 \\
\hline Mean VIF & 1.67 & \\
\hline Source: Authors' estimation. & & \\
\hline
\end{tabular}

Appendix E. Cross-Sectional Dependence, Heteroskedasticity, and Slope Homogeneity Tests

\begin{tabular}{cc}
\hline Breusch-Pagan LM Test of Independence & Coef. \\
\hline Chi-square test value: $\chi^{2}(36)$ & 134.156 \\
$p$-value & 0.0000 \\
\hline $\begin{array}{c}\text { Modified Wald test for groupwise } \\
\text { heteroskedasticity }\end{array}$ \\
\hline$\chi^{2}(10)$ & 509.54 \\
\hline$p$-value & 0.0000 \\
\hline Swamy slope homogeneity test & 41658.21 \\
Chi-square test value: $\chi^{2}(48)$ & 0.0000 \\
\hline$p$-value
\end{tabular}

Note: The null hypothesis of the cross-sectional dependence test is no cross-sectional dependence. The null hypothesis of the slope homogeneity test is slope homogeneity. The Cross-sectional dependence and slope homogeneity tests are conducted by using respectively 'xttest2' [100] and 'xtrchh2' [101] commands in Stata. Source: Authors' estimation. 


\section{Appendix F. Panel Unit Root Test}

\begin{tabular}{ccccc}
\hline \multirow{2}{*}{ Variable } & \multicolumn{2}{c}{ Level (CIPS) } & \multicolumn{2}{c}{ 1st Difference (CADF) } \\
\cline { 2 - 5 } & Intercept & Intercept and Trend & Intercept & Intercept and Trend \\
\hline REU & -2.055 & -1.883 & -0.913 & 1.004 \\
MHTE & -0.865 & -1.4615 & 1.977 & 1.2513 \\
INF & -1.683 & -2.435 & 0.671 & $-1.499 *$ \\
POPG & -3.124 & -2.536 & $-2.927^{* * *}$ & 5.047 \\
EMP & -1.507 & -1.670 & 1.081 & 1.339 \\
GDPPC & $-1.437^{* * *}$ & $-1.784^{* * *}$ & 0.839 & 1.452 \\
\hline
\end{tabular}

Note: ${ }^{* * *}$ and ${ }^{*}$ denote statistical significance at the $1 \%$ and $10 \%$ levels, respectively. The null hypothesis is nonstationarity. The panel unit root test is conducted by using the 'xtcips' command in Stata [102]. Source: Authors' estimation.

\section{References}

1. Nguyen, T.T.; Tenhunen, J. Review of integrated ecological-Economic analyses for bioenergy plants under climate change at local scale. Int. J. Clim. Chang. Strat. Manag. 2013, 5, 324-343. [CrossRef]

2. Beser, N.O.; Soyyigit, S. The effects of high technology export and per capita income on carbon emission: An investigation on G20 countries. Bus. Econ. Horiz. 2019, 15, 542-559.

3. Seyoum, B. The role of factor conditions in high-technology exports: An empirical examination. J. High. Technol. Manag. Res. 2004, 15, 145-162. [CrossRef]

4. OECD (Organisation for Economic Co-operation and Development). Technology Intensity Definition. Classification of manufacturing industries into categories based on R\&D intensities. In OECD Directories for Science, Technology and Industry Economic Analysis and Statistics Division; OECD: Paris, France, 2011; Volume 9.

5. Chen, S.; Du, X.; Huang, J.; Huang, C. The impact of foreign and indigenous innovations on the energy intensity of China's industries. Sustainability 2019, 11, 1107. [CrossRef]

6. MacKenzie, J.J. Technology growth curves: A new approach to reducing global $\mathrm{CO}_{2}$ emissions. Energy Policy 2003, 31, $1183-1187$. [CrossRef]

7. Bamati, N.; Raoofi, A. Development level and the impact of technological factor on renewable energy production. Renew. Energy 2020, 151, 946-955. [CrossRef]

8. Sadorsky, P. Renewable energy consumption, $\mathrm{CO}_{2}$ emissions and oil prices in the G7 countries. Energy Econ. 2009, 31, 456-462. [CrossRef]

9. Sadorsky, P. Renewable energy consumption and income in emerging economies. Energy Policy 2009, 37, 4021-4028. [CrossRef]

10. Payne, J.E. The causal dynamics between US renewable energy consumption, output, emissions, and oil prices. Energy Sources Part B 2012, 7, 323-330. [CrossRef]

11. Salim, R.A.; Rafiq, S. Why do some emerging economies proactively accelerate the adoption of renewable energy? Energy Econ. 2012, 34, 1051-1057. [CrossRef]

12. Lean, H.H.; Smyth, R. Will policies to promote renewable electricity generation be effective? Evidence from panel stationarity and unit root tests for 115 countries. Renew. Sustain. Energy Rev. 2013, 22, 371-379. [CrossRef]

13. Smyth, R. Are fluctuations in energy variables permanent or transitory? A survey of the literature on the integration properties of energy consumption and production. Appl. Energy 2013, 104, 371-378. [CrossRef]

14. Omri, A.; Nguyen, D.K. On the determinants of renewable energy consumption: International evidence. Energy 2014, 72, 554-560. [CrossRef]

15. Omri, A.; Daly, S.; Nguyen, D.K. A robust analysis of the relationship between renewable energy consumption and its main drivers. Appl. Econ. 2015, 47, 2913-2923. [CrossRef]

16. Alam, M.M.; Murad, M.W. The impacts of economic growth, trade openness and technological progress on renewable energy use in organization for economic co-operation and development countries. Renew. Energy 2020, 145, 382-390. [CrossRef]

17. Bakker, M.H.; Duncan, J.A. Future bottlenecks in international river basins: Where transboundary institutions, population growth and hydrological variability intersect. Water Int. 2017, 42, 400-424. [CrossRef]

18. Hasanov, F.J.; Liddle, B.; Mikayilov, J. The impact of international trade on $\mathrm{CO}_{2}$ emissions in oil exporting countries: Territory vs. consumption emissions accounting. Energy Econ. 2018, 74, 343-350. [CrossRef]

19. Mikayilov, J.I.; Galeotti, M.; Hasanov, F.J. The impact of economic growth on $\mathrm{CO}_{2}$ emissions in Azerbaijan. J. Clean. Prod. 2018, 197, 1558-1572. [CrossRef]

20. Sadorsky, P. Trade and energy consumption in the Middle East. Energy Econ. 2011, 33, 739-749. [CrossRef]

21. Shahbaz, M.; Nasreen, S.; Ling, C.H.; Sbia, R. Causality between trade openness and energy consumption: What causes what in high, middle and low income countries. Energy Policy 2014, 70, 126-143. [CrossRef]

22. Sohag, K.; Begum, R.; Abdullah, S.M.S.; Jaafar, M. Dynamics of energy use, technological innovation, economic growth and trade openness in Malaysia. Energy 2015, 90, 1497-1507. [CrossRef] 
23. Corcelli, F.; Fiorentino, G.; Vehmas, J.; Ulgiati, S. Energy efficiency and environmental assessment of papermaking from chemical pulp-A Finland case study. J. Clean. Prod. 2018, 198, 96-111. [CrossRef]

24. East-West Center. ASEAN Matters for America; East-West Center: Washington, DC, USA, 2019.

25. Azam, M.; Khan, A.Q.; Zaman, K.; Ahmad, M. Factors determining energy consumption: Evidence from Indonesia, Malaysia and Thailand. Renew. Sustain. Energy Rev. 2015, 42, 1123-1131. [CrossRef]

26. Mohsin, M.; Kamran, H.W.; Nawaz, M.A.; Hussain, M.S.; Dahri, A.S. Assessing the impact of transition from non-renewable to renewable energy consumption on economic growth-environmental nexus from developing Asian countries. J. Environ. Manag. 2021, 284, 1-8. [CrossRef]

27. Androniceanu, A.-M.; Căplescu, R.; Tvaronavičienè, M.; Dobrin, C. The interdependencies between economic growth, energy consumption and pollution in Europe. Energies 2021, 14, 2577. [CrossRef]

28. Grabara, J.; Tleppayev, A.; Dabylova, M.; Mihardjo, L.W.; Dacko-Pikiewicz, Z. Empirical research on the relationship amongst renewable energy consumption, economic growth and foreign direct investment in Kazakhstan and Uzbekistan. Energies 2021, 14, 332. [CrossRef]

29. Hsu, C.C.; Chien, F.; Ngo, Q.T.; Nguyen, T.D.; Vu, H.M.; Hugo, C. Nexus between energy security and economic development: Empirical evidence from BRICS economies. Singap. Econ. Rev. 2021, 165, 381-390. [CrossRef]

30. Nguyen, T.T.; Nguyen, T.-T.; Hoang, V.-N.; Wilson, C.; Managi, S. Energy transition, poverty and inequality in Vietnam. Energy Policy 2019, 132, 536-548. [CrossRef]

31. Bashir, M.A.; Sheng, B.; Doğan, B.; Sarwar, S.; Shahzad, U. Export product diversification and energy efficiency: Empirical evidence from OECD countries. Struct. Chang. Econ. Dyn. 2020, 55, 232-243. [CrossRef]

32. Ngo, Q.-T.; Nguyen, C.T. Do export transitions differently affect firm productivity? Evidence across Vietnamese manufacturing sectors. Post Communist Econ. 2020, 32, 1011-1037. [CrossRef]

33. Shahbaz, M.; Gozgor, G.; Hammoudeh, S. Human capital and export diversification as new determinants of energy demand in the United States. Energy Econ. 2019, 78, 335-349. [CrossRef]

34. Gozgor, G.; Can, M. Effects of the product diversification of exports on income at different stages of economic development. Eurasian Bus. Rev. 2016, 6, 215-235. [CrossRef]

35. Samargandi, N. Energy intensity and its determinants in OPEC countries. Energy 2019, 186, 115803. [CrossRef]

36. Lv, Y.; Chen, W.; Cheng, J. Direct and indirect effects of urbanization on energy intensity in Chinese cities: A regional heterogeneity analysis. Sustainability 2019, 11, 3167. [CrossRef]

37. Huo, T.; Ren, H.; Cai, W. Estimating urban residential building-related energy consumption and energy intensity in China based on improved building stock turnover model. Sci. Total Environ. 2019, 650, 427-437. [CrossRef] [PubMed]

38. Sun, H.; Edziah, B.K.; Sun, C.; Kporsu, A.K. Institutional quality, green innovation and energy efficiency. Energy Policy 2019, 135, 111002. [CrossRef]

39. Yan, H. Provincial energy intensity in China: The role of urbanization. Energy Policy 2015, 86, 635-650. [CrossRef]

40. Adom, P.K. Asymmetric impacts of the determinants of energy intensity in Nigeria. Energy Econ. 2015, 49, 570-580. [CrossRef]

41. Adom, P.K.; Minlah, M.K.; Adams, S. Impact of renewable energy (hydro) on electricity prices in Ghana: A tale of the short- and long-run. Energy Strat. Rev. 2018, 20, 163-178. [CrossRef]

42. Elliott, R.; Sun, P.; Chen, S. Energy intensity and foreign direct investment: A Chinese city-level study. Energy Econ. 2013, 40, 484-494. [CrossRef]

43. Yu, H. The influential factors of China's regional energy intensity and its spatial linkages: 1988-2007. Energy Policy 2012, 45, 583-593. [CrossRef]

44. Rafiq, S.; Salim, R.; Nielsen, I. Urbanization, openness, emissions, and energy intensity: A study of increasingly urbanized emerging economies. Energy Econ. 2016, 56, 20-28. [CrossRef]

45. Adom, P.K.; Kwakwa, P.A. Effects of changing trade structure and technical characteristics of the manufacturing sector on energy intensity in Ghana. Renew. Sustain. Energy Rev. 2014, 35, 475-483. [CrossRef]

46. Adom, P.K. Determinants of energy intensity in South Africa: Testing for structural effects in parameters. Energy 2015, 89, 334-346. [CrossRef]

47. Cole, M.A. Does trade liberalization increase national energy use? Econ. Lett. 2006, 92, 108-112. [CrossRef]

48. Barnsley, A.B.; Brown, A. Enabling Renewable Energy and Energy Efficiency Technologies: Opportunities in Eastern Europe, Caucasus, Central Asia, Southern and Eastern Mediterranean; International Energy Agency (IEA): Paris, France, 2015.

49. Fisher-Vanden, K.; Jefferson, G.H.; Liu, H.; Tao, Q. What is driving China's decline in energy intensity? Resour. Energy Econ. 2004, 26, 77-97. [CrossRef]

50. Zhou, N.; Levine, M.D.; Price, L. Overview of current energy-efficiency policies in China. Energy Policy 2010, $38,6439-6452$. [CrossRef]

51. Huang, J.; Hao, Y.; Lei, H. Indigenous versus foreign innovation and energy intensity in China. Renew. Sustain. Energy Rev. 2018, 81, 1721-1729. [CrossRef]

52. Borghesi, S.; Crespi, F.; D’Amato, A.; Mazzanti, M.; Silvestri, F. Carbon abatement, sector heterogeneity and policy responses: Evidence on induced eco innovations in the EU. Environ. Sci. Policy 2015, 54, 377-388. [CrossRef]

53. Mamun, A.; Sohag, K.; Shahbaz, M.; Hammoudeh, S. Financial markets, innovations and cleaner energy production in OECD countries. Energy Econ. 2018, 72, 236-254. [CrossRef] 
54. Rathore, N.S.; Panwar, N. Renewable Energy Sources for Sustainable Development; New India Publishing: New Delhi, India, 2007.

55. Strantzali, E.; Aravossis, K. Decision making in renewable energy investments: A review. Renew. Sustain. Energy Rev. 2016, 55, 885-898. [CrossRef]

56. Liu, S.; Xia, X.; Tao, F.; Chen, X. Assessing urban carbon emission efficiency in China: Based on the global data envelopment analysis. Energy Procedia 2018, 152, 762-767. [CrossRef]

57. Wang, Y.; Zhao, T.; Wang, J.; Guo, F.; Kan, X.; Yuan, R. Spatial analysis on carbon emission abatement capacity at provincial level in China from 1997 to 2014: An empirical study based on SDM model. Atmos. Pollut. Res. 2019, 10, 97-104. [CrossRef]

58. Zeng, L.; Lu, H.; Liu, Y.; Zhou, Y.; Hu, H. Analysis of regional differences and influencing factors on China's carbon emission efficiency in 2005-2015. Energies 2019, 12, 3081. [CrossRef]

59. Mathiesen, B.V.; Lund, H.; Karlsson, K. 100\% Renewable energy systems, climate mitigation and economic growth. Appl. Energy 2011, 88, 488-501. [CrossRef]

60. Menyah, K.; Wolde-Rufael, Y. $\mathrm{CO}_{2}$ emissions, nuclear energy, renewable energy and economic growth in the US. Energy Policy 2010, 38, 2911-2915. [CrossRef]

61. Apergis, N.; Payne, J.E. Renewable energy consumption and economic growth: Evidence from a panel of OECD countries. Energy Policy 2010, 38, 656-660. [CrossRef]

62. Fang, Z.; Chang, Y. Energy, human capital and economic growth in Asia Pacific countries-Evidence from a panel cointegration and causality analysis. Energy Econ. 2016, 56, 177-184. [CrossRef]

63. Oyedepo, S.O. Energy and sustainable development in Nigeria: The way forward. Energy Sustain. Soc. 2012, 2, 1-17. [CrossRef]

64. Ahmad, S.; Tahar, R.M. Selection of renewable energy sources for sustainable development of electricity generation system using analytic hierarchy process: A case of Malaysia. Renew. Energy 2014, 63, 458-466. [CrossRef]

65. Lund, H. Renewable energy strategies for sustainable development. Energy 2007, 32, 912-919. [CrossRef]

66. Kahia, M.; Ben Aïssa, M.S.; Lanouar, C. Renewable and non-renewable energy use-economic growth nexus: The case of MENA Net Oil Importing Countries. Renew. Sustain. Energy Rev. 2017, 71, 127-140. [CrossRef]

67. Le, H.P.; Sarkodie, S.A. Dynamic linkage between renewable and conventional energy use, environmental quality and economic growth: Evidence from emerging market and developing economies. Energy Rep. 2020, 6, 965-973. [CrossRef]

68. Marques, A.C.; Fuinhas, J.A. Drivers promoting renewable energy: A dynamic panel approach. Renew. Sustain. Energy Rev. 2011, 15, 1601-1608. [CrossRef]

69. Ahmed, S.; Alam, K.; Sohag, K.; Gow, J.; Rashid, A.; Akter, M. Renewable and non-renewable energy use and its relationship with economic growth in Myanmar. Environ. Sci. Pollut. Res. 2019, 26, 22812-22825. [CrossRef] [PubMed]

70. Sbia, R.; Shahbaz, M.; Hamdi, H. A contribution of foreign direct investment, clean energy, trade openness, carbon emissions and economic growth to energy demand in UAE. Econ. Model. 2014, 36, 191-197. [CrossRef]

71. Wan, J.; Baylis, K.; Mulder, P. Trade-facilitated technology spillovers in energy productivity convergence processes across EU countries. Energy Econ. 2015, 48, 253-264. [CrossRef]

72. Khan, M.T.I.; Yaseen, M.R.; Ali, Q. Dynamic relationship between financial development, energy consumption, trade and greenhouse gas: Comparison of upper middle income countries from Asia, Europe, Africa and America. J. Clean. Prod. 2017, 161, 567-580. [CrossRef]

73. Tweneboah, G.; Alagidede, P. Dollarization, inflation targeting, and inflationary dynamics in Ghana. J. Afr. Bus. 2019, 20, 358-375. [CrossRef]

74. Kosai, S.; Yuasa, M.; Yamasue, E. Chronological transition of relationship between intracity lifecycle transport energy efficiency and population density. Energies 2020, 13, 2094. [CrossRef]

75. Wang, W.; Yang, H.; Zhang, Y.; Xu, J. IoT-enabled real-time energy efficiency optimisation method for energy-intensive manufacturing enterprises. Int. J. Comput. Integr. Manuf. 2017, 31, 362-379. [CrossRef]

76. Rahman, M.; Vu, X.-B. Are energy consumption, population density and exports causing environmental damage in China? autoregressive distributed lag and vector error correction model approaches. Sustainability 2021, 13, 3749. [CrossRef]

77. Marques, A.C.; Fuinhas, J.A.; Manso, J.P. Motivations driving renewable energy in European countries: A panel data approach. Energy Policy 2010, 38, 6877-6885. [CrossRef]

78. Baltagi, B.H. Econometric Analysis of Panel Data; Springer Science and Business Media LLC: Berlin, Germany, 2021.

79. Arellano, M. On the testing of correlated effects with panel data. J. Econ. 1993, 59, 87-97. [CrossRef]

80. Wooldridge, J.M. Econometric Analysis of Cross Section and Panel Data; MIT Press: Cambridge, UK, 2010.

81. Seddigi, H.; Lawler, K.A. Econometrics: A Practical Approach; Routledge: New York, NY, USA, 2000.

82. Waheed, R.; Sarwar, S.; Mighri, Z. Role of high technology exports for energy efficiency: Empirical evidence in the context of Gulf Cooperation Council countries. Energy Environ. 2020, 0958305x20954196. [CrossRef]

83. Kennedy, P. A Guide to Econometrics; John Wiley and Sons: Hoboken, NJ, USA, 2008.

84. Goldberger, A.S. A Course in Econometrics; Harvard University Press: Cambridge, MA, USA, 1991.

85. Breusch, T.S.; Pagan, A.R. The lagrange multiplier test and its applications to model specification in econometrics. Rev. Econ. Stud. 1980, 47, 239-253. [CrossRef]

86. Greene, W.H. Econometric Analysis, 4th ed.; Prentice Hall: Upper Saddle River, NJ, USA, 2000; pp. 201-215.

87. Swamy, P.A.V.B. Efficient inference in a random coefficient regression model. Econometrica 1970, 38, 311-323. [CrossRef]

88. Grossman, G.M.; Krueger, A.B. Economic growth and the environment. Q. J. Econ. 1995, 110, 353-377. [CrossRef] 
89. Pesaran, M.H. A simple panel unit root test in the presence of cross-section dependence. J. Appl. Econ. 2007, 22, 265-312. [CrossRef]

90. Hoechle, D. Robust standard errors for panel regressions with cross-sectional dependence. Stata J. Promot. Commun. Stat. Stata 2007, 7, 281-312. [CrossRef]

91. Aïssa, M.S.B.; Jebli, M.B.; Youssef, S.B. Output, renewable energy consumption and trade in Africa. Energy Policy 2014, 66, 11-18. [CrossRef]

92. Yanikkaya, H. Trade openness and economic growth: A cross-country empirical investigation. J. Dev. Econ. 2003, 72, 57-89. [CrossRef]

93. Al-Mulali, U.; Ozturk, I.; Lean, H.H. The influence of economic growth, urbanization, trade openness, financial development, and renewable energy on pollution in Europe. Nat. Hazards 2015, 79, 621-644. [CrossRef]

94. Premik, F.; Stanisławska, E. The Impact of Inflation expectations on Polish consumers' spending and saving. East. Eur. Econ. 2017, 55, 3-28. [CrossRef]

95. Avina, J.M. City building energy efficiency programs: Hindering real energy efficiency? ... One practitioner's real world marketplace observations. Energy Eng. 2017, 114, 22-36. [CrossRef]

96. Carmi, N.; Tal, A. The perceived relationship between population growth and current ecological problems using repertory grid technique. Hum. Ecol. Risk Assess. Int. J. 2018, 25, 1773-1788. [CrossRef]

97. Füllemann, Y.; Moreau, V.; Vielle, M.; Vuille, F. Hire fast, fire slow: The employment benefits of energy transitions. Econ. Syst. Res. 2019, 32, 202-220. [CrossRef]

98. Allan, G.; McGregor, P.; Swales, K. Greening regional development: Employment in low-carbon and renewable energy activities. Reg. Stud. 2017, 51, 1270-1280. [CrossRef]

99. Halkos, G.; Gkampoura, E.-C. Coping with energy poverty: Measurements, drivers, impacts, and solutions. Energies 2021, 14, 2807. [CrossRef]

100. Baum, C.F. Residual diagnostics for cross-section time series regression models. Stata J. Promot. Commun. Stat. Stata 2001, 1, 101-104. [CrossRef]

101. Poi, B.P. From the help desk: Swamy's random-coefficients model. Stata J. 2003, 3, 302-308. [CrossRef]

102. Burdisso, T.; Sangiácomo, M. Panel time series: Review of the methodological evolution. Stata J. Promot. Commun. Stat. Stata 2016, 16, 424-442. [CrossRef] 